University of Nebraska - Lincoln

DigitalCommons@University of Nebraska - Lincoln

Papers in the Earth and Atmospheric Sciences

Earth and Atmospheric Sciences, Department

January 2006

\title{
Coupling between primary terrestrial succession and the trophic development of lakes at Glacier Bay, Alaska
}

D. R. Engstrom

St. Croix Watershed Research Station, Science Museum of Minnesota, Marine on St. Croix, MN,

dre@smm.org

Sherilyn C. Fritz

University of Nebraska-Lincoln, sfritz2@unl.edu

Follow this and additional works at: https://digitalcommons.unl.edu/geosciencefacpub

Part of the Earth Sciences Commons

Engstrom, D. R. and Fritz, Sherilyn C., "Coupling between primary terrestrial succession and the trophic development of lakes at Glacier Bay, Alaska" (2006). Papers in the Earth and Atmospheric Sciences. 26. https://digitalcommons.unl.edu/geosciencefacpub/26

This Article is brought to you for free and open access by the Earth and Atmospheric Sciences, Department of at DigitalCommons@University of Nebraska - Lincoln. It has been accepted for inclusion in Papers in the Earth and Atmospheric Sciences by an authorized administrator of DigitalCommons@University of Nebraska - Lincoln. 


\title{
Coupling between primary terrestrial succession and the trophic development of lakes at Glacier Bay, Alaska
}

\author{
D. R. Engstrom ${ }^{1, *}$ and S. C. Fritz ${ }^{2}$ \\ ${ }^{1}$ St. Croix Watershed Research Station, Science Museum of Minnesota, Marine on St. Croix, MN 55047, USA \\ ${ }^{2}$ Department of Geosciences and School of Biological Sciences, University of Nebraska-Lincoln, 214 Bessey \\ Hall, Lincoln, NE 68588-0340, USA \\ * Corresponding author, email dre@smm.org
}

\begin{abstract}
The natural eutrophication of lakes is still an accepted concept in limnology, arising as it does from the earliest efforts to classify lakes and place them in an evolutionary sequence. Recent studies of newly formed lakes at Glacier Bay, Alaska, only partially support this idea, and suggest more variable trends in lake trophic development which are under local (catchment-level) control. Here we use sediment cores from several lakes in Glacier Bay National Park to examine the relationship between successional changes in catchment vegetation and trends in water-column nitrogen (a limiting nutrient) and lake primary production. Terrestrial succession at Glacier Bay follows several different pathways, with older sites in the lower bay being colonized directly by spruce (Picea) and by-passing a prolonged alder (Alnus) stage that characterizes younger upper-bay sites. Sediment cores from three sites spanning this successional gradient demonstrate that the variability in nitrogen trends among lakes is a consequence of the establishment and duration of $\mathrm{N}$-fixing alder in the lake catchment. In the lower-bay lakes, diatom-inferred nitrogen concentrations rise and then fall in concert with the transient appearance of alder in the catchment, while in the upper bay, high nitrogen concentrations are sustained by the continuous dominance of alder. Diatom accumulation, a proxy for whole-lake biological productivity, increases steadily at all three sites during the first century following lake formation, but declines in more recent times at the lower-bay sites in apparent response to the disappearance of alder and decreasing lake-water nitrogen. These results demonstrate a tight biogeochemical coupling between terrestrial succession and lake trophic change during the early developmental history of Glacier Bay lakes.
\end{abstract}

Keywords: diatom accumulation, Glacier Bay, lake ontogeny, nitrogen, primary production, primary succession

\section{Introduction}

The evaluation of patterns and controls of natural lake aging has been a recurring theme in limnology since the work of Pearsall (1921) in the English Lake District. Because direct observation of lake ontogeny over centuries and millennia is impossible, limnologists have relied on sedimentary records to infer patterns of lake development and to derive hypotheses about the factors controlling the direction and rate of change (Binford and Deevey 1983). Some of the earliest paleolimnological studies focused on these autogenic (successional) processes and concluded that lake nutrient concentrations and productivity increased over time (Deevey 1942). Other sediment-based studies from boreal and north-temperate 
regions found that lakes became progressively more dilute and acidic from the leaching of base cations from catchment soils (Round 1961; Pennington et al. 1972; Whitehead et al. 1989; Ford 1990) and the increased inputs of dissolved organic carbon (DOC) from the accretion of soil organic matter (Huttunen et al. 1978; Renberg 1986).

These ideas of early lake development have been largely validated by studies from Glacier Bay, Alaska, where limnological change has been inferred from a chronosequence of modern lakes of different ages (Engstrom et al. 2000; Fritz et al. 2004). Here successional patterns were modeled by a space for time substitution in the same way that terrestrial succession was described in the classic work of plant ecologists at Glacier Bay (Cooper 1923; Crocker and Major 1955; Lawrence 1958). Results provide strong evidence that long-term soil development and related hydrological changes cause alkalinity and $\mathrm{pH}$ to decrease, DOC to increase, and nitrogen levels to rise and then fall over time. These changes span time-scales ranging from a few centuries to several thousand years.

However, a comparison of these general trends with the trajectories of individual lakes-as reconstructed from sediment cores-reveals site-specific differences, especially with respect to nutrient (nitrogen) concentrations (Fritz et al. 2004). These differences are thought to relate to successional trends in catchment vegetation, which have been shown to vary substantially between sites in upper and lower Glacier Bay. Rather than a single successional pathway from early colonizers to alder (Alnus) to spruce (Picea), terrestrial succession actually follows several pathways depending on seed availability and the life-history traits of the dominant species (Fastie 1995). Thus, older sites in the lower bay were colonized directly by spruce and effectively by-passed the prolonged alder stage that characterizes younger upper-bay sites. The variability in nitrogen trends among lake sites is thus explained as a consequence of the establishment and duration of N-fixing alder in the lake catchment.

Although highly plausible, the linkages described above between terrestrial succession and lake trajectories have not been established by direct comparison of local vegetational history with lake chemistry trends. Because lake sediments record both vegetation (through pollen) and lake chemistry (though di- atoms), it should be possible to test the hypothesis that the local presence of alder influences lake ontogeny at Glacier Bay. Thus, the purpose of this study is to explore in greater detail the consequences of contrasting pathways in terrestrial succession on lake trophic development-in particular, nitrogen levels and primary productivity. The study lakes are particularly well-suited to this task, as most are small (15 ha surface area) and thus have a strong local-pollen signature, and are nitrogen limited, so that fossil diatom assemblages provide a robust indicator of historical lake-water N. Moreover, the accumulation rate of diatoms in the sediments provides a direct measure of diatom productivity, a major component of total primary production for lakes in this region. Diatoms are well preserved in most sediments (unlike carbon), and sediments integrate year-round diatom production from all habitats, including benthic, which is not captured in any manner by conventional measurement of water-column productivity.

\section{Study sites}

Glacier Bay National Park and Preserve, located in southeastern Alaska (at approximately $58^{\circ} \mathrm{N}$, $136^{\circ} \mathrm{W}$ ), is renowned world-wide for its catastrophic recession of neoglacial ice, which exposed a 100$\mathrm{km}$ long fjord system and associated forelands to biotic colonization and primary succession. Classical studies of this invasion sequence (e.g., Cooper 1923; Lawrence 1958; Reiners et al. 1971) depict early colonization by plants such as mountain avens (Dryas drummondii), fireweed (Epilobium latifolium), and dwarf willows (Salix sp.), followed by shrub thickets of alder (Alnus crispa vs. sinuata) that are in turn replaced by a closed forest of spruce (Picea sitchensis) and associated conifers. Recent studies describe a more complex sequence that results in different stable outcomes-spruce forest, cottonwood stands (Populus balsamifera), or alder thickets-depending on proximity of sites to seed-sources on unglaciated surfaces (Fastie 1995).

Our original study of lakes in Glacier Bay National Park included 32 sites ranging in age from 10 years to $>10,000$ years (Engstrom et al. 2000). Three lakes from this original set are the focus of the current study; these are Bartlett Lake, located adjacent 
to the terminal neoglacial moraine, Lester Island (Lester-1 in the original chronosequence), also located in the lower bay but in the Beardsley Islands and far from the terminal moraine, and Blue Mouse Cove at the lower end of the west arm of the Glacier Bay fjord (Figure 1 and Table 1). Lake elevations are all $<30 \mathrm{~m}$ a.s.l. The first two sites, Bartlett Lake and Lester Island, occupy land surfaces deglaciated about 200 years ago and are today vegetated by closed spruce/hemlock (Tsuga heterophylla) forest. The third site at Blue Mouse Cove is approximately 110 years old and has a catchment cloaked in dense alder thickets with scattered spruce and cottonwood poking through the alder canopy. The lakes range from 4.0 to 8.0 m maximum depth. Bartlett Lake is moderate in size (62 ha), whereas the other two lakes are small (1.7-3.5 ha). By virtue of their location, these sites constitute a historical experiment in which dis- tance from the terminal moraine (and spruce seed source) is expected to influence successional pathways, both terrestrial and limnological.

\section{Methods}

Sediment cores were collected from the deepwater zone of each lake with a piston corer operated from the lake surface by rigid drive rods. Cores were sectioned in the field at $0.5-1.0 \mathrm{~cm}$ intervals and later analyzed for diatoms and pollen and dated by ${ }^{210} \mathrm{~Pb}$. Organic matter content of the sediments was determined by standard loss-on-ignition (LOI) methods (Heiri et al. 2001). Subsamples for diatom analysis were oxidized in $\mathrm{HNO}_{3} / \mathrm{K}_{2} \mathrm{Cr}_{2} \mathrm{O}_{7}$, dried onto coverslips, and mounted with Naphrax ${ }^{\circledR}$. A minimum of 400 individual diatoms was counted at $1000 \times$ un-

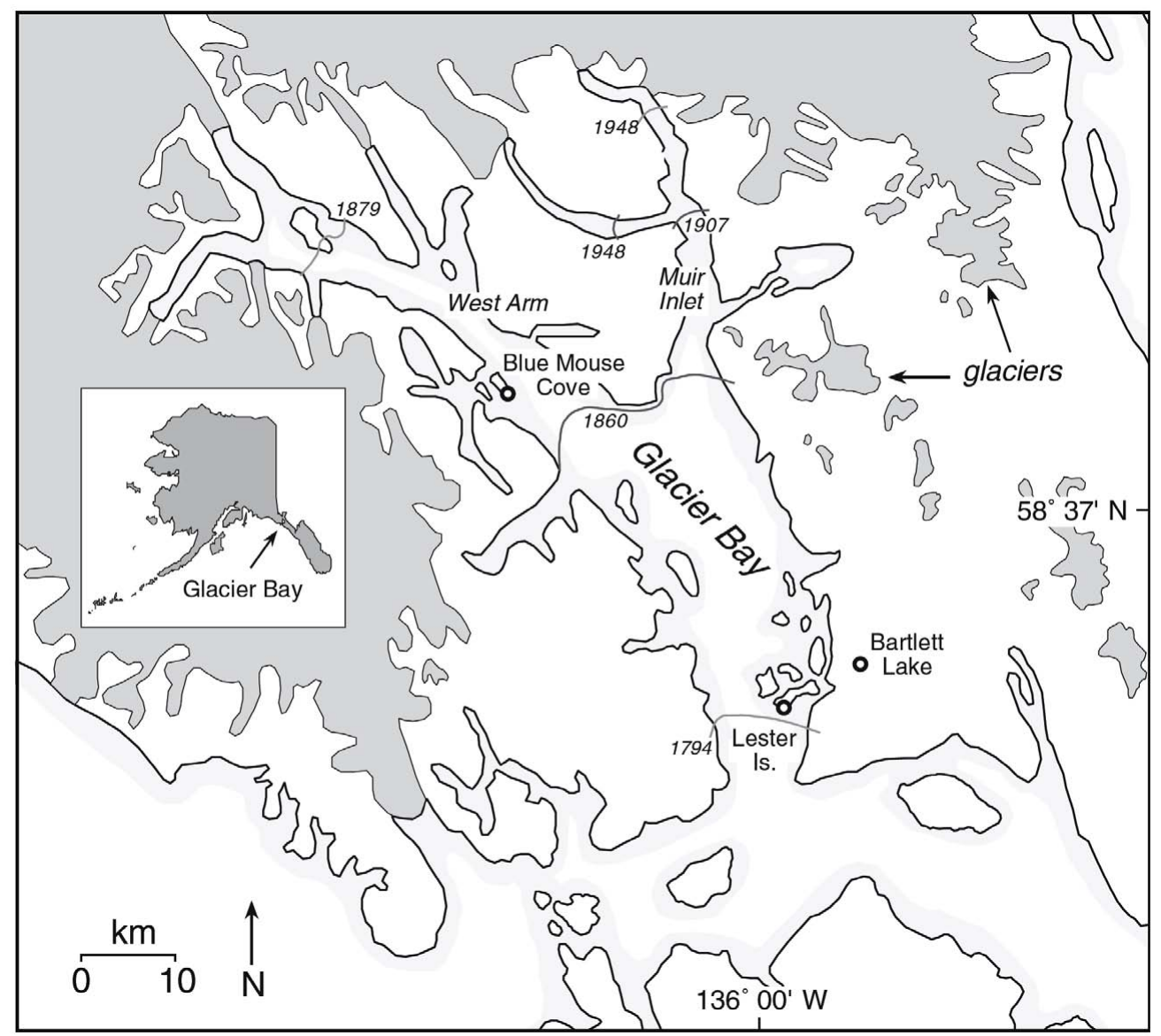

Figure 1. Map of Glacier Bay National Park and Preserve showing the lake sites discussed in the text; Neoglacial ice margins are marked by dated isochrons. 
Table 1. Location and water chemistry of study lakes.

\begin{tabular}{lcccccccc}
\hline Site & Lat (N) & Long (W) & $\mathrm{pH}$ & $\begin{array}{l}\text { Cond. } \\
\mu \mathrm{S} \mathrm{cm}^{-1}\end{array}$ & $\begin{array}{l}\mathrm{Ca} \\
\mathrm{mg} \mathrm{L}^{-1}\end{array}$ & $\begin{array}{l}\text { Total-N } \\
\mathrm{ppb}\end{array}$ & $\begin{array}{l}\text { Total-P } \\
\mathrm{ppb}\end{array}$ & $\begin{array}{l}\text { DOC } \\
\mathrm{mg} \mathrm{L}^{-1}\end{array}$ \\
\hline Blue Mouse & $58^{\circ} 20.9^{\prime}$ & $136^{\circ} 21.6^{\prime}$ & 7.47 & 75 & 12.40 & 338 & 8.1 & 5.42 \\
Lester Island & $58^{\circ} 30.0^{\prime}$ & $135^{\circ} 48.1^{\prime}$ & 6.27 & 21 & 1.31 & 295 & 9.9 & 5.12 \\
Bartlett Lake & $58^{\circ} 27.4^{\prime}$ & $135^{\circ} 56.0^{\prime}$ & 6.19 & 8 & 0.56 & 1227 & .9 & 2.11 \\
\hline
\end{tabular}

der oil immersion. Diatom concentrations were determined by spiking samples with a calibrated microsphere solution (Battarbee et al. 2001). Standard laboratory procedures were used to prepare subsamples for pollen analysis (Fægri and Iversen 1989); a total of 200-250 pollen grains and spores were counted. Lead-210 was measured by ${ }^{210}$ Po-distillation and alpha-spectrometry methods, and dates were determined according to the c.r.s. (constant rate of supply) model (Appleby 2001).

Each lake in the chronosequence was sampled for water chemistry and limnological variables $(\mathrm{pH}$, alkalinity, nutrients, major ions, DOC, chlorophyll $a$; Table 1) a minimum of three times over a 3-year period to assess seasonal and inter-annual variability (Engstrom et al. 2000; Fritz et al. 2004). The relationship between diatom distributions and water chemistry was then explored using canonical correspondence analysis (CCA) and detrended CCA (ter Braak 1986). Total-nitrogen (TN) was found to explain a significant and independent fraction of the total variation in the diatom data set, and TN trends were reconstructed from fossil diatom assemblages by using a weighted averaging (WA) transfer function $\left(r^{2}=0.71\right.$, RMSE $\left.=1.29\right)($ Fritz et al. 2004).

\section{Results}

The recovered sediment cores range in length from 10 to $20 \mathrm{~cm}$ and consist of a thin veneer of greenish lacustrine gyttja overlying dense gray glacial silt. The contact between the two sedimentary units is fairly sharp, with the lacustrine sediments becoming increasingly flocculent and organic-rich toward the top of the core (Figure 2a). This contact represents the deglaciation and stabilization of the newly formed lake basins and the onset of terrestrial and aquatic succession. It occurs at 9-11 cm in the two older lakes from the lower bay (Bartlett Lake and
Lester Island) and at $4 \mathrm{~cm}$ in the younger lake at Blue Mouse Cove.

The profiles for ${ }^{210} \mathrm{~Pb}$ are consistent with sediment stratigraphy and the known history of deglaciation of the study sites. Total ${ }^{210} \mathrm{~Pb}$ decreases monotonically through the gyttja layer from surface activities of 9$33 \mathrm{pCi} \mathrm{g}^{-1}$ to background (supported) values of $0.5-$ $0.7 \mathrm{pCi} \mathrm{g}^{-1}$ at the contact with the underlying glacial silts (Figure 2b). The downcore trends are non-exponential, indicating changing rates of sediment accumulation during maturation of the landscape. Core chronologies calculated by the c.r.s. model yield basal dates that roughly match the deglaciation history of Glacier Bay (Figure 1): ca. 1820 for Bartlett Lake and Lester Island and 1880 for Blue Mouse Cove. Trends in sediment accumulation (Figure 2c) follow a similar pattern for the two older sites, Bartlett Lake and Lester Island. Rates are highest during the early history of the lakes, decline steadily to minimum values ca. 1940, and rise thereafter. Blue Mouse Cove, although lacking detail in the early period, exhibits much the same pattern.

Pollen data reveal distinct differences in vegetational development among the study sites, which are explicable in terms of the different pathways that primary succession follows in the upper and lower parts of Glacier Bay (Fastie 1995). Core trajectories projected onto a biplot of the two major pollen types, Alnus (alder) and Picea (spruce), show increasing percentages of alder during the early histories of the three sites (Figure 3a). This trend is quickly reversed at Bartlett Lake by increasing percentages of spruce pollen, and similarly so, but with a greater delay, at Lester Island. The Bartlett Lake trajectory differs from Lester Island by higher spruce ( $>40 \%$ at present) and lower alder (generally $<50 \%$ ) overall. Blue Mouse Cove, on the other hand, shows steadily increasing alder throughout the entire sequence, with percentages equal to those found in surface sediment samples at 

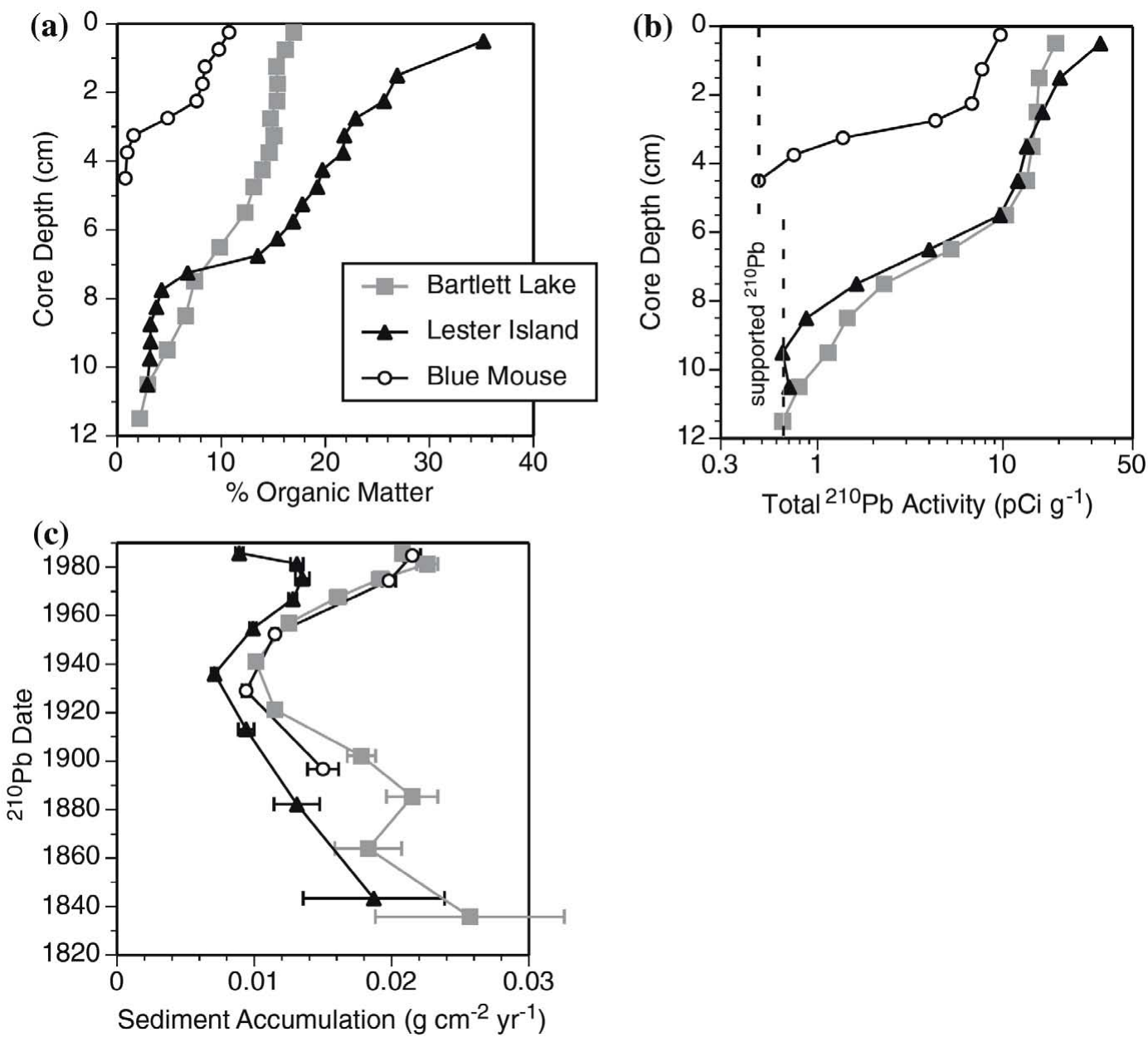

Figure 2. Profiles of $\%$ organic matter (a), total ${ }^{210} \mathrm{~Pb}(\mathrm{~b})$, and sediment accumulation (c) for cores from the three study lakes. Dates and sediment accumulation rates were determined by ${ }^{210} \mathrm{~Pb}$ and the constant rate of supply (c.r.s.) model; error bars represent \pm 1 SD propagated from counting uncertainty.

other sites in Muir Inlet (all less than 80 years old). It should be noted that spruce and especially alder are very strong pollen producers, such that together they make up greater than $70 \%$ of the pollen sum in most of the analyzed samples.

The core trajectory for Bartlett Lake thus describes local vegetational succession that is dominated at the outset by spruce- - a consequence of the site's proximity (ca. $4 \mathrm{~km}$ ) to spruce seed sources on the eastern flank of the Glacier Bay terminal moraine-with only a minor and transient alder component. Blue Mouse Cove, on the other hand, shows alder dominance throughout its history on account of the rapid migration of alder onto the glacial forelands of the upper bay. The Lester Island site, although located in the lower bay, is more distant (about $10 \mathrm{~km}$ ) from the nearest neoglacial conifer refugium and thus shows an intermediate pattern with the early development of a healthy alder component and its subsequent replacement by an advancing spruce forest. These pollen-based trends are consistent with the successional patterns inferred by Fastie (1995) from tree-ring and stand-origin data. Fastie's results showed that sites $>7 \mathrm{~km}$ from mature forests were invaded by alder thickets following deglaciation, while sites $<5 \mathrm{~km}$ away were invaded directly by spruce.

Diatom-based reconstructions of nitrogen levels in the three lakes follow trends that are consistent with the contrasting patterns of vegetational succession shown by pollen analysis Figure 3b). In 

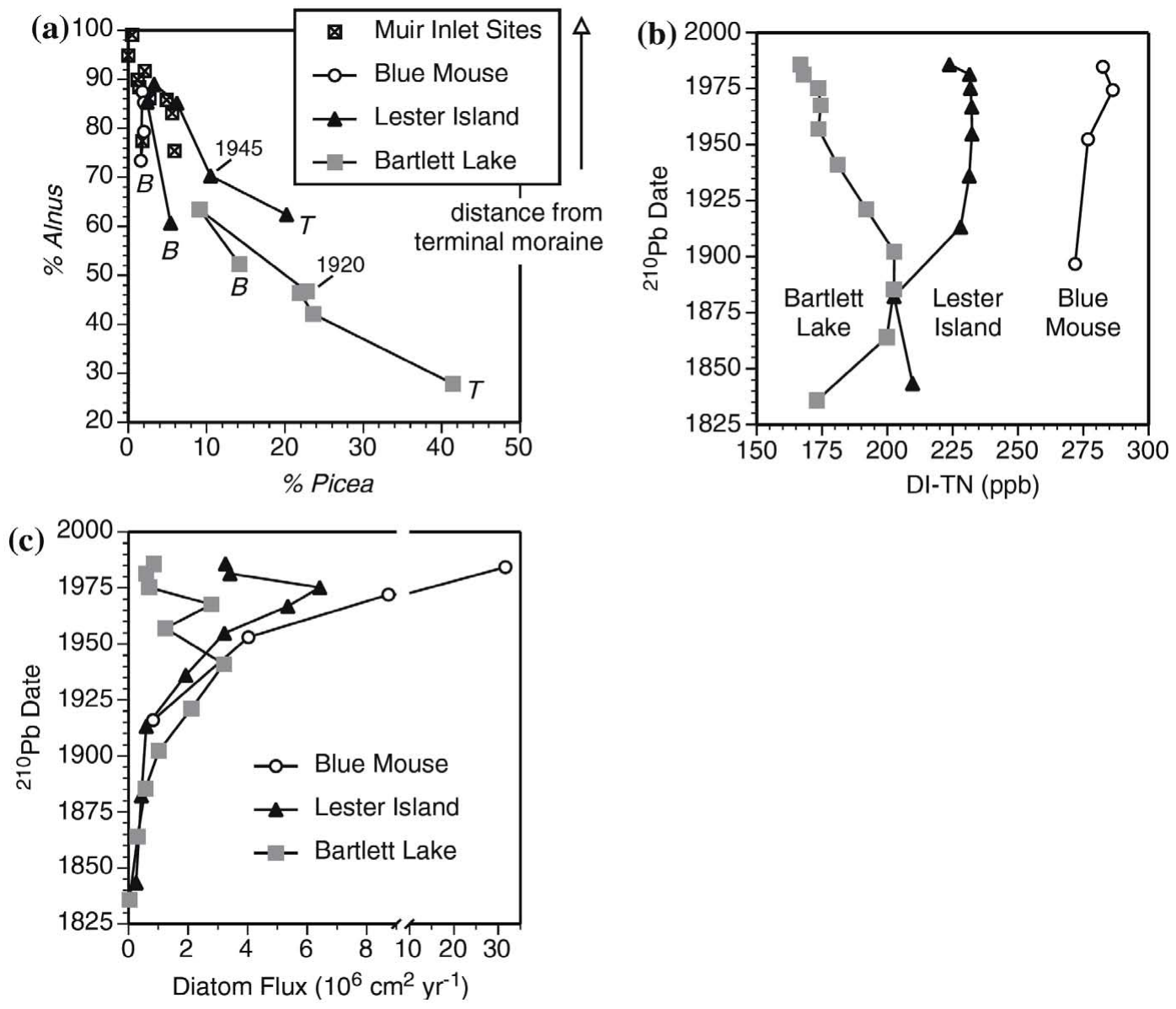

Figure 3. Sediment proxies representing catchment vegetation (a), lake-water total-nitrogen (b), and whole-lake primary production (c) for the three study lakes. Vegetational trends (a) are represented by changing percentages of the two major pollen types, spruce (Picea) and alder (Alnus); for each lake, "T" denotes the core top (modern) and "B" the base of the core; dates shown for major declines in \% Alnus. TN trends (b) are reconstructed from fossil diatom assemblages using a weighted averaging (WA) transfer function as described in Fritz et al. (2004); TN uncertainty, back-transformed from the RMSEP, is approximately $\pm 70 \mathrm{ppb}$. Primary production (c) is represented by the accumulation rate of diatoms in each of the three cores.

Bartlett Lake, diatom-inferred TN levels rise early in the lake's history, peak between 1850 and 1900, and then decline gradually to the present. TN levels show a similar (though slightly delayed) increase at Lester Island, with elevated concentrations persisting to near modern times. Blue Mouse Cove exhibits steady or slightly increasing TN values throughout its shorter record. Diatom-inferred TN is consistently higher at Blue Mouse Cove than at Lester Island, which in turn is higher than at Bartlett Lake. These trends are explicable in terms of the successional importance of N-fixing alder in the lakes' catchments. The early and brief appearance of alder at Bartlett Lake is manifest in a transient rise in $\mathrm{TN}$, while a more persistent and dominant alder phase at the western end of Lester Island produces higher and sustained lake-water TN. Blue Mouse Cove, with its complete alder dominance and high lake TN, completes the upper end of this experimental gradient.

Diatom accumulation rates (flux), which reflect whole-lake biological productivity-diatoms are the dominant algal group in these lakes-follow somewhat different trajectories in each of the three lakes (Figure 3c). In all cases diatom flux (and concentration) is lowest during early lake development $(<0.1 \times$ $10^{6}$ valves $\mathrm{cm}^{-2}$ year $^{-1}$ ) and rises steadily for the first 100 years or so following deglaciation. Values peak for Bartlett Lake ca. 1940 (3.2 × 10 $0^{6}$ valves $\mathrm{cm}^{-2}$ 
year $^{-1}$ ) and decline irregularly thereafter, while at Lester Island the peak is delayed until ca. 1975 and is also somewhat higher $\left(6.4 \times 10^{6}\right.$ valves $\mathrm{cm}^{-2}$ year $\left.^{-1}\right)$. Blue Mouse Cove, by contrast, shows an exponential increase in diatom accumulation to a present-day maximum of $32 \times 10^{6}$ valves $\mathrm{cm}^{-2}$ year $^{-1}$. The rise and fall in diatom flux at Bartlett Lake and Lester Island correspond fairly closely with the trends in diatom-inferred TN, although the decline appears to lag slightly that for TN. At Blue Mouse Cove, the monotonic rise in diatom accumulation matches the steady increase in lake-water TN.

It should be noted that diatom accumulation rates derived from single cores may be biased by withinlake variability in sediment deposition. However, in all three cores diatom concentration follows the same stratigraphic pattern as diatom flux, which means that accumulation rates are not simply an artifact of changing patterns of sediment deposition. Moreover, the ${ }^{210} \mathrm{~Pb}$ inventories in the cores - which provide a rough measure of sediment focusing-are highest in Bartlett Lake (13.2 pCi cm${ }^{-2}$ ) and lowest in Blue Mouse (6.7 $\mathrm{pCi} \mathrm{cm}^{-2}$ ). Correcting the diatom fluxes in Figure $3 \mathrm{c}$ for sediment focusing would thus accentuate the differences in productivity among the three lakes (i.e., Blue Mouse would be relatively higher and Bartlett Lake lower than indicated by the single core data).

\section{Discussion}

The diatom and pollen profiles from these three contrasting sites demonstrate an internally consistent linkage between local vegetational succession and the biogeochemical development of the receiving lakes. The multi-successional pathways of terrestrial succession at Glacier Bay, as described by Fastie (1995), are confirmed by pollen trends that demonstrate temporal and spatial differences in the local appearance and dominance of $\mathrm{N}$-fixing alder thickets. Alder abundance is then correlated with the changing concentrations of lake-water TN, which in turn is manifest in differential patterns of diatom productivity in the lakes.

In all cases, there is an initial rise in lake productivity that is consistent with some of the earliest hypotheses regarding lake ontogeny (Pearsall 1921; Thienemann 1931; Naumann 1932; Deevey 1942). For the period of record contained in these young lakes, this rise is dependent on sustained inputs of nitrogen from catchment vegetation. The successional development of spruce forests at the two lower-bay sites is accompanied by a gradual loss of $\mathrm{N}$ from the water column and a reduction in diatom production. Such oligotrophication is likely a consequence of overall lower soil $\mathrm{N}$ in the lower bay (where extensive alder thickets were never present) along with decreased nutrient availability as limited $\mathrm{N}$ pools became sequestered in living and dead biomass (Bormann and Sidle 1990).

The diatom-inferred TN trajectories would suggest that soil $\mathrm{N}$ levels are tightly linked via runoff to those in lake-water. The near-absence of alder in the early history of the Bartlett Lake catchment is thus manifest in overall lower $\mathrm{N}$ levels in the lake, while the abundant alder at Blue Mouse Cove leads to high and sustained lake-water N. Similar observations on the role of alder in stimulating lake productivity have been reported by $\mathrm{Hu}$ et al. (2001) from a site in southwestern Alaska. Here the early-Holocene expansion of alder was accompanied by a large increase in sedimentary concentrations of biogenic $\mathrm{Si}$, decreasing C: $\mathrm{N}$ ratios, and increasing $\delta^{15} \mathrm{~N}$.

Bioassay experiments in some of these same Glacier Bay lakes indicate strong N-limitation on benthic diatom production and assemblage composition (Olson 1998). These results are consistent with empirical measures of nutrient limitation (nitrate:totalphosphorus ratios), demonstrating the importance of nitrogen supply in controlling primary production in Glacier Bay lakes (Engstrom et al. 2000). Thus, the changing flux of diatoms in the sediment cores is mechanistically linked to TN levels in the lake and ultimately to successional changes in catchment vegetation. Diatom accumulation, as a proxy for lake productivity, can be biased by species shifts to larger or smaller forms, especially a change from large benthic taxa to small planktonic species. However, the diatom sequences at these sites are dominated throughout by benthic forms, and there is no systematic size shift that would explain the observed accumulation trends (Fritz et al. 2004).

The importance of local differences in hydrology, geology, and terrestrial succession in controlling lake development have been emphasized in our previous discussions of the Glacier Bay chronosequence. What we demonstrate here is just how tight the bio- 
geochemical coupling is between terrestrial succession and lake development. These results imply that autogenic succession in lakes-especially small lakes, as those studied here-is largely a deterministic consequence of primary succession in the terrestrial catchment.

\section{Acknowledgements}

We thank Jim Almendinger, Barbara Coffin, Jan Janssens, Ed Swain, and Herb Wright for assistance in the field, and Gustavus residents Sandy Burd, Mary Hervin, Bob Howe, and Greg Streveler, and NPS and USGS staff at Glacier Bay National Park for logistical support. Barbara Hansen performed the pollen analysis, and Steve Juggins assisted with the diatom numerical analysis. Financial support was provided by the NSF Ecology Program and by the late D.B. Lawrence. This paper is dedicated to the memory of Geoff Seltzer who was a colleague and companion on many of our Glacier Bay adventures.

\section{References}

Appleby P.G. 2001. Chronostratigraphic techniques in recent sediments. In: Last W.M. and Smol J.P. (eds), Tracking Environmental Change Using Lake Sediments. Volume 1: Basin Analysis, Coring, and Chronological Techniques. Kluwer Academic Publishers, Dordrecht, pp. 171-203.

Battarbee R.W., Jones V.J., Flower R.J., Cameron N.G., Bennion H., Carvalho L. and Juggins S. 2001. Diatoms. In: Smol J.P., Birks H.J.B. and Last W.M. (eds), Tracking Environmental Change Using Lake Sediments Volume. 3: Terrestrial, Algal, and Siliceous Indicators. Kluwer, Dordrecht, pp. 155-202.

Binford M.W. and Deevey E.S. 1983. Paleolimnology: an historical perspective on lacustrine ecosystems. Ann. Rev. Ecol. Syst. 14: 255-286.

Bormann B.T. and Sidle R.C. 1990. Changes in productivity and distribution of nutrients in a chronosequence at Glacier Bay National Park, Alaska. J. Ecol. 78: 561-578.

Cooper W.S. 1923. The recent ecological history of Glacier Bay, Alaska: II. The present vegetation cycle. Ecology 4: 223-246.

Crocker R.L. and Major J. 1955. Soil development in relation to vegetation and surface age at Glacier Bay, Alaska. J. Ecol. 43: 427-448.

Deevey E.S. 1942. Studies on Connecticut Lake sediments. III. The biostratonomy of Linsley Pond. Am. J. Sci. 240: 313-324.

Engstrom D.R., Fritz S.C., Almendinger J.E. and Juggins S. 2000. Chemical and biological trends during lake evolution in recently deglaciated terrain. Nature 408: 161-166.

Fægri K. and Iversen J. 1989. Textbook of Pollen Analysis. Wiley, New York, 328 pp.
Fastie C.L. 1995. Causes and ecosystem consequences of multiple successional pathways of primary succession at Glacier Bay, Alaska. Ecology 76: 1899-1916.

Ford M.S. 1990. A 10,000-yr history of natural ecosystem acidification. Ecol. Monogr. 60: 57-89.

Fritz S.C., Engstrom D.R. and Juggins S. 2004. Patterns of early lake evolution in boreal landscapes: a comparison of stratigraphic inferences with a modern chronosequence in Glacier Bay, Alaska. Holocene 14: 828-840.

Heiri O., Lotter A.F. and Lemcke G. 2001. Loss on ignition as a method for estimating organic and carbonate content in sediments: reproducibility and comparability of results. J. Paleolimnol. 25: 101-110.

Hu F.S., Finney B.P. and Brubaker L.B. 2001. Effects of Holocene Alnus expansion on aquatic productivity, nitrogen cycling, and soil development in southwestern Alaska. Ecosystems 4: 358-368.

Huttunen P., Meriläinen J. and Tolonen K. 1978. The history of a small dystrophied forest lake, southern Finland. Pol. Arch. Hydrobiol. 25: 189-202.

Lawrence D.B. 1958. Glaciers and vegetation in southeastern Alaska. Am. Scient. 46: 89-122.

Naumann E. 1932. Grundzuge der regionalen limnologie. Die Binnengewasser 11: 1-176.

Olson O.G. 1998. Mechanisms controlling long-term changes in periphytic diatom community structure, Ph.D. Thesis, Lehigh University, 112 pp.

Pearsall W.H. 1921. The development of vegetation in the English Lakes, considered in relation to the general evolution of glacial lakes and rock basins. Proc. R. Soc. B 92: 259-284.

Pennington W., Haworth E.Y., Bonny A.P. and Lishman J.P. 1972. Lake sediments in northern Scotland. Phil. Trans. R. Soc. B 264: 191-294.

Reiners W.A., Worley I.A. and Lawrence D.B. 1971. Plant diversity in a chronosequence at Glacier Bay, Alaska. Ecology 52: 55-69.

Renberg I. 1986. A sedimentary diatom record of severe acidification in Lake Blamissusjo“ n, N. Sweden, through natural soil processes. In: Smol J.P., Battarbee R.W. and Meriläinen J. (eds), Diatoms and Lake Acidity. Dr W. Junk Publishers, Dordrecht, pp. 213-219.

Round F.E. 1961. The diatoms of a core from Esthwaite Water. New Phytol. 60: 43-59.

ter Braak C.J.F. 1986. Canonical correspondence analysis: a new eigenvector method for multivariate direct gradient analysis. Ecology 67: 1167-1179.

Thienemann A. 1931. Tropische seen und seetyplehre. Arch. Hydrobiol. 9: 205-231.

Whitehead D.R., Charles D.F., Jackson S.T., Smol J.P. and Engstrom D.R. 1989. The developmental history of Adirondack (N.Y.) lakes. J. Paleolimnol. 2: 185-206. 